\title{
Identification and detection of Salmonella strains isolated from chicken carcasses and environmental sources in Dourados, MS, Brazil
}

\author{
Fabíola Fatima das Chagas ${ }^{1}$, Bruno do Amaral Crispim ${ }^{2 \star}$, Kelly Mari Pires de Oliveira ${ }^{2}$, and \\ Alexeia Barufatti Grisolia ${ }^{2}$
}

\author{
${ }^{1}$ Faculdade de Ciências Exatas e Tecnologia, Universidade Federal da Grande Dourados - MS, Brazil. \\ ${ }^{2}$ Faculdade de Ciências Biológicas e Ambientais, Universidade Federal da Grande Dourados -MS, Brazil.
}

Accepted 29 April, 2013

\begin{abstract}
The application of methodologies that can rapidly and precisely identify Salmonella in both foods and water samples is of great interest to public health. Salmonella sp. was isolated from chicken carcasses and water samples from aquaculture tanks using both traditional culture methods and bacteriological analyses. DNAs from these isolates were extracted and Multiplex Polymerase Chain Reactions (mPCR) were performed using primers for invA, fliC and sefA genes to detect the genus Salmonella and to differentiate the serovars Typhimurium and Enteritidis respectively. The results of these bacteriological analyses indicated that $94 \%$ of the chicken carcass samples were contaminated by 46 Salmonella sp. strains. mPCR analyses indicated that $\mathbf{4 3}$ of these strains belonged to the genus Salmonella. Among these isolates, $32 \%$ were genotyped as Salmonella enteritidis while none were identified as Salmonella typhimurium. Bacteriological analyses of the aquaculture tank water samples indicated that $73 \%$ were contaminated, and 11 Salmonella sp. strains were isolated; mPCR analyses indicated that all of them belonged to the genus Salmonella, but no $S$. enteritidis and S. typhimurium serovars were identified. Multiplex PCR was found to be a very sensitive test that allowed rapid and reliable identification of these bacteria.
\end{abstract}

Key words: Salmonella enteritidis, Salmonella typhimurium, bacteriological analyses, multiplex polymerase chain reactions, aquaculture.

\section{INTRODUCTION}

Salmonellosis has become a serious problem in many countries in recent decades. Salmonella is among the main causal agents of infectious diseases passed by contaminated foods and water (Malorny et al., 2003) and these illnesses have high annual costs to public health throughout the world. The economic cost of salmonellosis in the United States alone was more than $\$ 2.6$ billion dollars in 2009. According to Health Ministry of Brazil data, there were 6971 reported cases of food-transmitted illnesses between 1999 and 2010, and Salmonella sp. was the contaminating agent in $46 \%$ of those cases. The global increase in chicken consumption stimulated by its high protein content (similar to beef) and its accessible price has drawn the attention of producers, researchers and authorities to the necessity of controlling Salmonella contamination, principally during the various stages of commercial production chains. In light of that fact that chicken meat is almost exclusively sold while frozen, it will be important to assess its involvement in the spread of Salmonella. The capacity of Salmonella to survive 
outside its host for relatively long periods of time adds an important dimension to the epidemiology of salmonellosis. Salmonella present in the natural environment represents a serious risk to animal production and public health, making constant monitoring of upmost importance (Cavada et al., 2010). In addition to its ingestion in contaminated foods, salmonellosis can also be spread by contaminated water (Kozlica et al., 2010). While Salmonella has only rarely been reported in aquaculture tanks, more detailed investigations and monitoring are needed due to significant global increases in fish production and consumption.

The genus Salmonella comprises 2579 serovars (Grimont and Weill, 2007). The serovars most frequently isolated in humans (Soumet et al., 1999) and in outbreaks of illnesses transmitted by foods (Herikstad et al., 2002) are Salmonella enteritidis and Salmonella typhimurium. Isolates of $S$. enteritidis have shown expressive increases in frequency in every part of the world since the 1980s, and more recent studies have shown $S$. enteritidis to be the most prevalent global serovar (Amini et al., 2010; Hassanein et al., 2011). Starting in the 1990s, samples of avian origin in Brazil began to show significant increases in $S$. enteritidis and $S$. enteritidis isolates in Salmonella samples of human origin sent to the Adolfo Lutz Institute in São Paulo increased from 1.2 to $64.9 \%$ between 1991 and 1995 (Tavechio et al., 1996). The identification of the genus Salmonella using conventional bacteriological analyses is laborious and time consuming and not compatible with routine processing of large numbers of samples (Mainali et al., 2011). Serovar confirmations using traditional methodologies must be performed in reference laboratories and in a country as large as Brazil only the Oswaldo Cruz Institute can perform these analyses, causing significant research delays. Consequently, the introduction of methodologies that could securely identify the principal serovars of Salmonella would be very important for rapid diagnoses (Silva et al., 2011).

Polymerase Chain Reaction (PCR) is a simple, rapid, very specific, reliable, and relatively inexpensive technique (Rampersad et al., 2008) that has been widely used in detecting Salmonella sp. and in differentiating serovars of greatest importance to public health. Most of the virulence factors in Salmonella are bar-coded in genes grouped in various genetically stable Salmonella Pathogenity Islands (SPI) in the bacterial chromosome. SPI1 is present in all of the phylogenetic lines of the genus Salmonella but absent in other bacteria (such as E. coli). SPI1 contains genes (among them invA) that code for proteins necessary for pathogen entry into the epithelial cells lining the host's intestines (Galán, 1996). The sefA gene (fimbrial antigen of $S$. enteritidis), specific for the detection of the Enteritidis serovar, was identified in all of the strains of $S$. enteritidis isolated from birds, pigs, humans and cattle, but in no other serovar tested (Murugkar et al., 2003). The fliC gene (a flagellar gene of
Salmonella) is responsible for the expression of a flagellar protein specific to $S$. typhimurium (Soumet et al., 1999).

The development of tests that would allow efficient and rapid confirmations of water or food contamination by Salmonella would be very important to health officials and the food industry in Mato Grosso do Sul State, Brazil. The present study analyzed frozen chicken carcasses and water samples from aquaculture tanks in Dourados-MS for Salmonella using both standard bacteriological analyses and mPCR as an alternative method to test for the presence of the genus Salmonella and to specifically identify Enteritidis and Typhimurium serovars.

\section{MATERIALS AND METHODS}

\section{Obtaining samples}

Analyses were performed on 36 samples of chicken carcasses available at local market in Dourados, Mato Grosso do Sul state (MS), Brazil. We selected chickens randomly that had been obtained from abattoirs in MS state. The material was transported under refrigeration to the microbiology laboratory at UFGD for processing and analyses. Water analyses were performed using 15 samples taken from aquaculture tanks. The water samples were stored in sterile glass flasks and transported under refrigeration to the microbiology laboratory for subsequent analyses.

\section{Microbiological analyses of the food and water samples}

According to the methodology recommended by APHA (2001), $25 \mathrm{~g}$ of different parts of the chicken carcasses were homogenized in $225 \mathrm{ml}$ of sterile buffered peptone (Oxoid). The pond water samples were processed by homogenizing $10 \mathrm{ml}$ of water with $90 \mathrm{ml}$ of sterile buffered peptone (Oxoid). The samples (water or chicken) were incubated for $24 \mathrm{~h}$ at $37^{\circ} \mathrm{C}$ (pre-enrichment), and $1 \mathrm{ml}$ of this pre-enrichment liquid was transferred to $10 \mathrm{ml}$ of Selenite Cystine broth (SC - Acumedia) and 0.1 to $10 \mathrm{ml}$ Rappaport Vassiliadis broth (RV - Isofar) (selective enrichment). The broths were incubated at $37^{\circ} \mathrm{C}$ for $24 \mathrm{~h}(\mathrm{SC})$ or at $42^{\circ} \mathrm{C}$ for $48 \mathrm{~h}(\mathrm{RV})$. A sterilized platinum loop was used to transfer samples from each of the two selective enrichment broths to petri dishes containing Hektoen Enteric agar (Merck) that were incubated at $37^{\circ} \mathrm{C}$ for $24 \mathrm{~h}$. The colonies with characteristics of Salmonella sp. (1 to $2 \mathrm{~mm}$ in diameter, with darkened centers and a colorless halo) were submitted a biochemical tests using the Triple Sugar Iron agar (TSI - Merck) and Motility Indole Lysine Medium (MIL - Merck). The isolates with biochemical profiles typical of Salmonella were submitted to serum agglutination reactions on slides using polyvalent Salmonella serum (Probac) to confirm the diagnosis.

Results were verified by conventional serotyping methods using Probac on basis of the bacterial cell wall antigenic components according to the Kauffman-White scheme. Subsequent confirmations of the genus and detection of the Enteritidis and Typhimurium serovars of these isolates were performed using multiple PCR.

\section{Positive and negative control strains}

The positive ( $S$. enteritidis and $S$. typhimurium) and negative ( $E$. coli, Proteus mirabilis and Citrobacter sp.) control strains were obtained from the Food Microbiology Laboratory of the Department 
Table 1. Microorganisms, target genes, sequences and sizes of the amplified fragments.

\begin{tabular}{|c|c|c|c|c|c|}
\hline & Bacteria & Target gene & Primer sequence $5^{\prime}$ - 3' & $\begin{array}{l}\text { Fragment } \\
\text { size (bp) }\end{array}$ & Reference \\
\hline Genus & Salmonella sp. & $\operatorname{inv} A$ & $\begin{array}{l}\text { F - GTGAAATTATCGCCACGTTCGG } \\
\text { R - TCATCGCACCGTCAAAGG }\end{array}$ & 284 & $\begin{array}{l}\text { Rahn et al. } \\
\text { (1992) }\end{array}$ \\
\hline \multirow{2}{*}{ S. enterica serovar } & Typhimurium & flic & $\begin{array}{l}\text { F - CGGTGTTGCCCAGGTTGGTAAT } \\
\text { R - ACTGGTAAAGATGGCT }\end{array}$ & 620 & $\begin{array}{l}\text { Soumet et } \\
\text { al. (1997) }\end{array}$ \\
\hline & Enteritidis & sefA & $\begin{array}{l}\text { F - GCCGTACACGAGCTTATAGA } \\
\text { R - ACCTACAGGGGCACAATAAC }\end{array}$ & 250 & $\begin{array}{l}\text { Soumet et } \\
\text { al. (1997) }\end{array}$ \\
\hline
\end{tabular}

of Clinical and Biomedical Analyses at the State University of Maringá (UEM) at Maringá/PR.

\section{DNA genomic extraction}

Bacterial isolates from the chicken carcasses and the pond water that had been identified as the genus Salmonella using the serum agglutination reaction, as well as positive and negative control strains that had been held on nutrient agar, were reactivated in buffered peptone water at $37^{\circ} \mathrm{C}$ for $24 \mathrm{~h}$. The samples were diluted in sterile saline solution (85\%) in the proportions of $9: 1(9 \mathrm{ml}$ of the saline solution and $1 \mathrm{ml}$ of the buffered peptone water containing the bacteria). The samples diluted in saline solution were submitted to DNA extraction using chloroform, as adapted from Wilson et al. (1992). $300 \mu \mathrm{L}$ aliquots of each solution were placed in $2 \mathrm{~mL}$ microtubes and $2.5 \mu \mathrm{L}$ of proteinase $\mathrm{K}$ (Bioline) $(20 \mathrm{mg} / \mathrm{ml})$ and 500 $\mu \mathrm{L}$ of $20 \%$ sodium dodecyl sulfate-Vetec (SDS) were added and the mixture homogenized in a vortex, and incubated at $60^{\circ} \mathrm{C}$ in a water bath for $2 \mathrm{~h}$. After incubation, $800 \mu \mathrm{L}$ of chloroform were added and the solutions were agitated until completely homogenized, $350 \mu \mathrm{L}$ of protein precipitation solution were added and the mixture homogenized in a vortex. The samples were centrifuged at 18.000 $\mathrm{x} \mathrm{g}$ for $10 \mathrm{~min}$, the liquid phase was removed and transferred to another microtube and $1 \mathrm{ml}$ of $100 \%$ ethanol was added. The material was centrifuged again at $13.000 \times \mathrm{g}$ for $5 \mathrm{~min}$, the supernatant discarded, and $1 \mathrm{ml}$ of $70 \%$ ethanol was added. The mixture was centrifuged again for $2 \mathrm{~min}$ and the supernatant again discarded. The microtube was inverted to dry the sediment and $100 \mu \mathrm{L}$ of TE (Tris-EDTA) pH 8.7 with $0.1 \mu \mathrm{L}$ of RNase (Fermentas) (10 $\mathrm{mg} / \mathrm{ml}$ ) was added.

The isolated DNA was re-suspended in TE and incubated at $37^{\circ} \mathrm{C}$ for $1 \mathrm{~h}$ and stored in a freezer at $-20^{\circ} \mathrm{C}$.

\section{Quantitative and qualitative analyses of DNA}

The quantity and purity of the DNA extracted from each sample was determined by measuring its optical density in a spectrophotometer (NanoDrop ${ }^{\circledR}$ ND-1000 UV-Vis). Additionally, $10 \mu \mathrm{L}$ of DNA, with added $2 \mu \mathrm{L}$ of Blue Orange Loading Dye buffer (Fermentas) was submitted to electrophoresis in $2 \%$ agarose gel colored with ethidium bromide. The DNA was visualized in the gel and photographically registered under UV light.

\section{PCR and primers}

The DNA samples were submitted to multiplex polymerase chain reactions (mPCR) adapted from Santos et al. (2001). Three pairs of primers were used: one primer sequence to detect the genus Salmonella (gene $\operatorname{inv} A$ ) and the others to identify the two serovars (Fli15-Typ04, selected from the fliC gene and specific for $S$. typhimurium; and S1 to S4, selected from the sefA gene associated with virulence and specific for $S$. enteritidis). The oligonucleotide primer sequences and their expected product sizes were listed in Table 1. All the primer sequences were synthesized by Integrated DNA Technologies (IDT), USA.

\section{DNA amplification and detection}

The PCR amplification was performed in $25 \mu \mathrm{L}$ of reaction mixture containing $12.5 \mu \mathrm{L}$ of PCR Master Mix (Fermentas), $1.5 \mu \mathrm{L}(10$ $\mathrm{pM} / \mu \mathrm{L}$ ) of each of the primers and 10 to $50 \mathrm{ng}$ of genomic DNA. The polymerase chain reactions were run in a thermal cycler (Biorad) and consisted of initial denaturation at $94^{\circ} \mathrm{C}$ for $5 \mathrm{~min}$ before initiating the 35 cycles, each of which consisted of holding at $94^{\circ} \mathrm{C}$ for $30 \mathrm{~s}$, at $55^{\circ} \mathrm{C}$ for $30 \mathrm{~s}$ for primer annealing and extension, at $72^{\circ} \mathrm{C}$ for $30 \mathrm{~s}$ catalyzed by DNA polymerase activity, with a final extension for $7 \mathrm{~min}$ at $72^{\circ} \mathrm{C}$. All of the reactions were performed using a negative control in which the DNA was substituted by an equal volume of ultra-pure water. The reproducible natures of the tests were confirmed by running each isolate twice. We also used DNA from control strains of $S$. enteritidis, $S$. thyphimurium, E. coli, Proteus mirabilis and Citrobacter sp. The multiplex PCR products were added to the loading buffer (Fermentas) and submitted to electrophoresis in $2 \%$ agarose gel. The gel was prepared using TBE buffer colored with ethidium bromide $(10 \mathrm{mg} / \mathrm{ml})$. The products amplified sizes were identified using 50 base pair DNA ladder (Promega).

The amplified products were visualized under UV Transilluminator using Gel Documentation System and photographed using a photo documentation system (UVP).

\section{Tests of the genomic Salmonella sp. DNA sensitivity}

DNA samples of Salmonella containing $21 \mathrm{ng} / \mu \mathrm{L}$ were diluted with DNA-free water at $1: 10^{0}, 10^{-1}, 10^{-2}, 10^{-3}, 10^{-4}, 10^{-5}, 10^{-6}, 10^{-7}, 10^{-8}$ and $10^{-9}$ and subjected to same PCR amplification. $2 \mu \mathrm{L}$ of each sample were added to the PCR reagents, using only the primers for the invA gene, following the protocol described earlier.

\section{RESULTS}

Thirty-four isolates were identified from the chicken carcasses analyzed as having the biochemical profile of 
Table 2. Contamination samples and Salmonella isolates identified by biochemical tests and multiplex PCR.

\begin{tabular}{|c|c|c|c|}
\hline \multicolumn{2}{|l|}{ Samples analyzed } & Chicken carcasses & Pond water \\
\hline \multicolumn{2}{|l|}{ № of samples collected } & 36 & 15 \\
\hline \multicolumn{2}{|c|}{ Numbers of contaminated samples detected by biochemical tests } & 34 & 11 \\
\hline \multicolumn{2}{|l|}{ Numbers of contaminated samples detected by PCR } & 32 & 11 \\
\hline \multicolumn{2}{|c|}{ Total number of Salmonella isolates confirmed by biochemical tests } & 46 & 11 \\
\hline \multirow{3}{*}{ Numbers of Salmonella isolates confirmed by mPCR } & Salmonella sp. & 43 & 11 \\
\hline & S. Enteritidis & 14 & 0 \\
\hline & S. Typhimurium & 0 & 0 \\
\hline
\end{tabular}

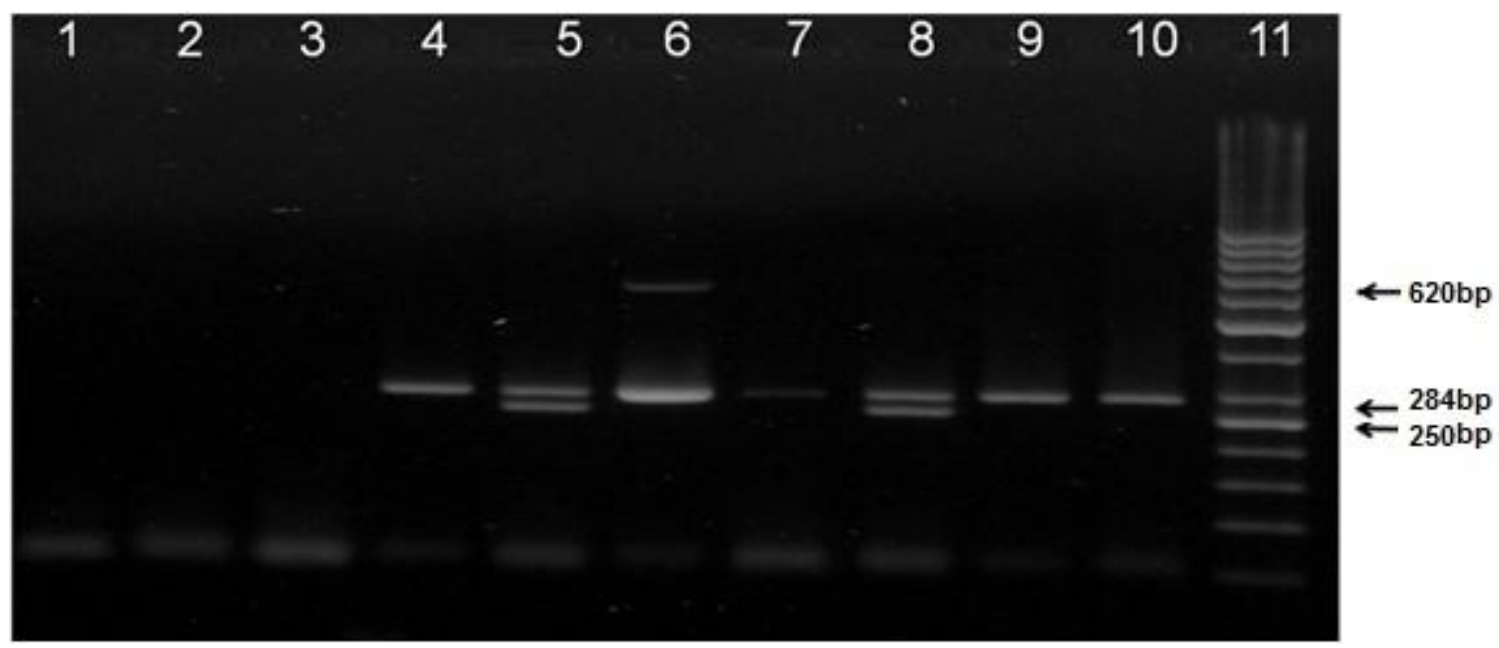

Figure 1. Agarose gel electrophoresis of the amplified products of multiplex PCR to determine the strains of the genus Salmonella (gene invA, $284 \mathrm{pb}$ ) in isolates of chicken carcasses and fish pond water and to identify Enteritidis (gene $\operatorname{sef} A, 250 \mathrm{pb}$ ) and Typhimurium (gene fliC, $620 \mathrm{pb}$ ) serotypes. Lane 1: negative control; lane 2: Proteus mirabilis; lane 3: Citrobacter sp.; lanes 4, 5 and 6: positive controls for Salmonella sp., Salmonella enteritidis, and Salmonella typhimurium respectively; lanes 7 and 8: chicken carcass samples; lanes 9 and 10: aquaculture water samples; lane 11: 50 pb molecular weight marker.

Salmonella sp. in Selenite Cystine broth, and 12 isolates in the Rappaport Vassiliadis broth, totaling 46 isolates demonstrated agglutination in sero-agglutination tests, confirming the diagnosis of the genus Salmonella. A contamination rate of $94 \%$ of the chicken carcasses was observed in this analysis (Table 2). The 46 Salmonella $\mathrm{sp}$. isolates confirmed by serum agglutination were submitted to multiplex PCR (mPCR). The amplifications of the $\mathrm{mPCR}$ products were visualized in agarose gel and a 284 base pair fragment (gene invA) was identified in the positive samples for the genus Salmonella; a 250 base pair fragment (gene sefA) for the samples belonging to the Enteritidis serovar and a 620 base pair fragment (gene $f(i C)$ for the samples belonging to the Typhimurium serovar (Figure 1). It was confirmed that 43 of the 46 isolates belonged to the genus Salmonella, and among these, 14 were identified as $S$. enteritidis. The Typhimurium serovar was not detected among these studied samples. A contamination rate of $89 \%$ of the chicken carcasses was confirmed by mPCR. Of the 15 analyses of water from aquaculture tanks, 11 (73\%) tested positive for Salmonella sp. using bacteriological analysis and were confirmed by mPCR, although the Enteritidis and Typhimurium serovars were not detected in any of these samples.

The isolates of Salmonella sp. from the chicken carcasses and/or aquaculture tank water samples demonstrated average genomic DNA contents of $5.39 \mu \mathrm{g} / \mu \mathrm{L}$. The ratio of their absorbances at $260 / 280$ yielded an average of 1.84 , indicating an acceptable degree of purity. The limits of detection by PCR using oligonucleotides primers to amplify the Salmonella invA gene are shown in Figure 2. When the genomic DNA of Salmonella $\mathrm{sp}$. was tested using dilutions with ultra-pure water, a specific band at $284 \mathrm{bp}$ could be seen at concentrations of $42 \mathrm{fg} / \mu \mathrm{L}$. These results demonstrated the sensitivity of the analyses used in the present work, permitting the detection of this pathogen even in samples with reduced DNA concentrations. 


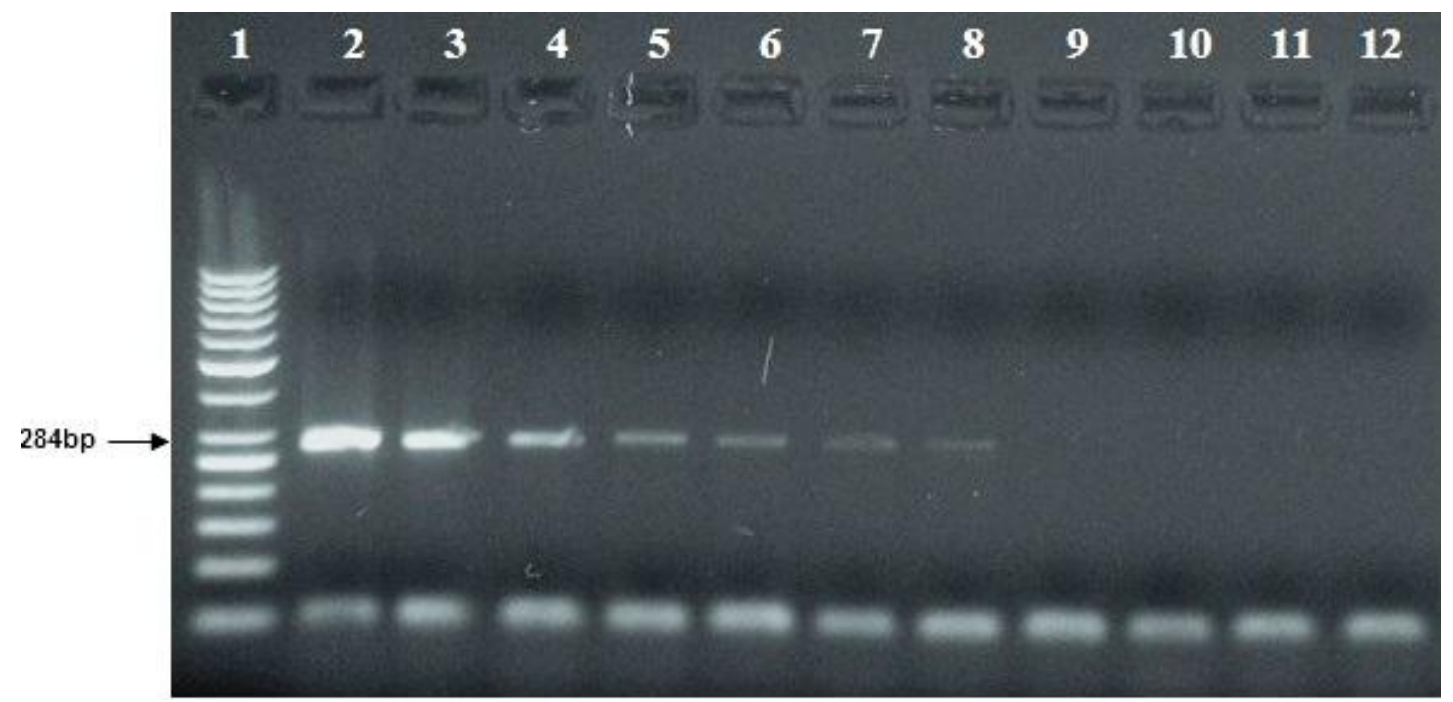

Figure 2. Agarose gel electrophoresis results showing the sensitivity of the PCR assay for the detection of genomic DNA of Salmonella sp. using invA gene (284 pb). Lane 1: 50 pb molecular weight marker; lane 12: negative control; lanes 2 to 11: $42 \mathrm{ng}, 4.2 \mathrm{ng}, 0.42 \mathrm{ng}, 42 \mathrm{pg}, 4.2 \mathrm{pg}, 420 \mathrm{fg}, 42 \mathrm{fg}, 4.2 \mathrm{fg}, 0.42 \mathrm{fg}$ and $42 \mathrm{ag}$ of genomic DNA diluted in ultra-pure water respectively.

\section{DISCUSSION}

Recent research has indicated wide variations in the rates of chicken carcass contaminations by Salmonella sp. in Brazil and in other countries, but most studies have reported indices well below the rates encountered here. Contamination rates of $16 \%$ were detected in Iran (Salehi et al., 2005). Antunes et al. (2003) detected $60 \%$ contamination by Salmonella sp. in Portugal, with prevalence of the Enteritidis serovar. Uyttendaele et al. (1998) reported contamination rates of $19,24,22$ and $37 \%$ in chicken carcasses in Belgium in the year 1993 to 1996, respectively. Malkawi et al. (2004) reported contamination rates of $30 \%$ in Jordan, with $49 \%$ of the isolates being identified as $S$. typhimurium and $47 \%$ as the Enteritidis serovar - data which goes against an apparent global tendency of the presence of $S$. enteritidis, as well as the data observed in the present work - indicating that the prevalences of different serovars in different regions of the world can vary greatly. Santos et al. (2000) analyzed 150 frozen chicken carcasses in São Paulo State and detected Salmonella sp. in $48(32 \%)$, of which $60 \%$ were of the Enteritidis serovar. Duarte et al. (2009) encountered contamination rates of $9.6 \%$ in Pernambuco State, of which $25 \%$ were identified as $S$. enteritidis. Boni et al. (2011) detected Salmonella in 257 samples from various processing steps in abattoirs located in the central region of Mato Grosso do Sul State and found a contamination rate of $11 \%$ for Salmonella. The differences in these contamination percentages are probably related to numerous factors, including the origin of the chicken lots, the hygiene-sanitary conditions in the abattoirs, and cross-contamination that occurred during plucking, washing, cooling and wrapping.
The carcasses are also susceptible to additional contamination during transport and commercialization (Corry et al., 2002). In addition to chickens, fishes are considered healthy alternative foods with low caloric value, and fish consumption by humans has greatly increased, principally in coastal cities and those near major rivers (Almeida et al., 2002). Fresh water fish production in Dourados-MS grew by 567\% between 1999 and 2002, reaching fully $62 \%$ of the total production of Mato Grosso do Sul state by 2002, although, inadequate hygiene practices, lack of worker training, inadequate nutritional programs, and poorly planned installations have compromised the microbiological quality of the water. These conditions can result the contamination of fish by a wide variety of microorganisms and making it an important vector of pathogenic agents, including Salmonella, with numerous outbreaks among human populations (Liuson, 2003). PCR of the invA gene represents a relatively lowcost but specific test that has the advantage of generating results within just a few hours after isolating the bacteria in selective media. Another advantage of PCR of the invA gene is that it is capable of specifically identifying $S$. enterica among other Enterobacteriaceae (Nucera et al., 2006). The invA gene of Salmonella contains unique sequences of this genus and has been shown to be an adequate target for PCR for diagnostic purposes (Rhan et al., 1992). This gene is recognized internationally as a standard for detecting the genus Salmonella, and its amplification has been used by many workers to detect contamination (Malorny et al., 2003; Jeyasekaran et al., 2011) in chicken carcasses (Salehi et al., 2005; Hassanein et al., 2011) and environmental samples (Moganedi et al., 2007). Of the 46 Salmonella isolates from chicken carcasses tested in the present work, 43 were confirmed 
using mPCR.

Jamshidi et al. (2009) working in Iran was able to identify all of the isolates examined as being representatives of Salmonella genes by way of replication of the invA gene (using the same primer employed in this research). The lack of confirmation of three isolates in the present work by PCR may indicate that some serovars cannot be detected using this gene. This observation corroborates the conclusions of Rahn et al. (1992) that some Salmonella serovars such as Salmonella litchfield and Salmonella senftenberg could not be detected by PCR. The fliC gene is responsible for the expression of a protein known as flagellin in Salmonella sp. the sefA gene codes for the fimbrial protein SEF14 that has unique specificity to $S$. enteritidis and its amplification can be used to identify this serovar (Thorns et al., 1996).

Researchers have used the specific sequences of these genes to detect $S$. typhimurium and $S$. enteritidis. Rahn et al. (1992) reported a detection limit of $27 \mathrm{pg} / \mathrm{\mu L}$, Stone et al. (1994) reported $30 \mathrm{pg} / \mu \mathrm{L}$, Upadhyay et al. (2010) noted $10 \mathrm{pg} / \mu \mathrm{L}$, Santos et al. (2001) reported 63 $\mathrm{fg} / \mu \mathrm{L}$ similar that we observed in this research, $42 \mathrm{fg} / \mu \mathrm{L}$. The confirmation of the presence of Salmonella using mPCR yielded results similar to traditional bacteriological methods - but reduced the time necessary for those analyses (Jofre et al., 2005). The simultaneous application of more than one DNA region of interest in a single PCR reduces the work effort, time, costs and risks of cross-contamination. As such, various authors (Freitas et al., 2010; Silva et al., 2011) have standardized mPCR to detect the presence of Salmonella and its serovars that are important in food safety and public health.

The contamination levels of chicken carcasses detected in the present work were high, indicating the necessity of better hygiene and sanitary conditions in the various stages of chicken production in Mato Grosso do Sul State, Brazil. There is likewise a need to establish more efficient water quality controls in aquaculture tanks located in the region around Grande Dourados-MS, Brazil. Although, our results are still preliminary, they strongly indicate that $\mathrm{mPCR}$ assays are an effective alternative to traditional methods of identification and differentiation of the most relevant Salmonella types. They could be used to rapidly and reliably confirm the presence of the genus Salmonella, including the Enteritidis and Typhimurium serovars (two of the most relevant agents in terms of human contamination by Salmonella). The use of mPCR assays would make it possible to establish parameters for studies requiring large numbers of samples - principally in studies directed toward the rapidly growing sector of aquaculture in the region around Dourados, MS.

\section{ACKNOWLEDGMENTS}

The authors would like to thank the Fundação de Apoio ao Desenvolvimento do Ensino, Ciência e Tecnologia do
Estado de Mato Grosso do Sul (FUNDECT) for their financial support of this work, and the Laboratório de Microbiologia de Alimentos do Departamento de Análises Clínicas e Biomedicina da Universidade Estadual de Maringá (UEM) for providing the control strains.

\section{REFERENCES}

Almeida Filho ES, Sigarini CO, Ribeiro JN, Delmondes EC, Stelatto E, Araújo Júnior A (2002). Características microbiológicas de "Pintado" (Pseudoplatystoma fasciatum) comercializado em supermercados e feira livre, no município de Cuiabá-MT. Hig. Aliment. 16(99): 84-88.

Amini K, Salehi TZ, Nikbakht G, Ranjbar R, Amini J, Ashrafganjooei SB (2010). Molecular detection of invA and $s p v$ virulence genes in Salmonella enteritidis isolated from human and animals in Iran. Afr. J. Microbiol. Res. 4(21): 2202-2210.

Antunes P, Réu C, Sousa JC, Peixe L, Pestana N (2003). Incidence of Salmonella from poultry products and their susceptibility to antimicrobial agents. Int. J. Food. Microbiol. 82: 97-103.

APHA (2001). American Public Health Association. Compendium of methods for the microbiological examination of foods. Washington, pp. 676.

Boni HFK, Carrijo AS, Fascina VB (2011). Ocorrência de Salmonella spp. em aviários e abatedouro de frangos de corte na região central de Mato Grosso do Sul. Rev. Bras. Saúde. Prod. Ani. 12(1): 84-95.

Cavada CA, Cardoso FM, Schmidt V (2010). Comparação de três metodologias para quantificação de Salmonella sp. em efluentes de sistemas de tratamento de dejetos. Acta. Sci. Vet. 38:17-23.

Corry JLE, Allen VM, Hudson WR, Breslin MF, Davies RH (2002). Sources of Salmonella on broiler carcasses during transportation and processing: modes of contamination and methods of control. J. Appl. Microbiol. 92: 424-432.

Duarte DAM, Ribeiro AR, Vasconcelos AMM, Santos SB, Silva JVD, Andrade PLA, Falcão LSPCA (2009). Occurrence of Salmonella spp. In broiler chicken carcasses and their susceptibility to antimicrobial agents. Braz. J. Microbiol. 40: 569-573.

Freitas CG, Santana AP, Silva PH, Gonçalves VS, Barros MA, Torres FA, Murata LS, Perecmanis S (2010). PCR multiplex for detection of Salmonella enteritidis, typhi and typhimurium and occurrence in poultry meat. Int. J. Food. Microbiol. 139: 15-22.

Galán JE (1996). Molecular genetics bases of Salmonella entry into host cells. Mol. Microbiol. 20: 263-271.

Grimont PAD, Weill FX (2007). Antigenic formulas of the Salmonella serovars.WHO Collaborating Centre for Reference and Research on Salmonella. Institut Pasteur, Paris, France.

Hassanein R, Ali SFH, El-Malek AMA, Moemen AM, Elsayh KI (2011). Detection and identification of Salmonella species in minced beef and chicken meats by using Multiplex PCR in Assiut city. Vet. World 4(1): 5-11.

Herikstad H, Motarjemi Y, Tauxe RV (2002). Salmonella surveillance: a global survey of public health serotyping. Epidemiol. Infect. 129(1):1-8.

Jamshidi A, Bassami MR, Afshari-Nic S (2009). Identification of Salmonella spp. and Salmonella Typhimurium by a multiplex PCRbased assay from poultry carcasses in Mashhad- Iran. Int. J. Vet. Res. 3(1): 43-48

Jeyasekaran G, Raj K, Shakila R, Thangarani A, Sukumar D, Jailani V (2011). Rapid detection of Salmonella enterica serovars by multiplex PCR. World. J. Microbiol. Biotechnol. 27: 953-959.

Jofre AB, Martin M, Garrigaa M, Hugas M, Rodriguez-Lazarp PD, Aymerich $T$ (2005). Simultaneous detection of Listeria monocytogenes and Salmonella by multiplex PCR in cooked ham. Food. Microbiol. 22: 109-115.

Kozlica J, Claudet AL, Solomon D, Dunn JR, Carpenter LR (2010). Waterborne outbreak of Salmonella I 4,[5],12:i:-. Foodborne. Pathog. Dis. 7: 1431-3.

Liuson E (2003). Pesquisa de coliformes totais, fecais e Salmonella spp. em tilápias de pesqueiros da região metropolitana de São Paulo. Dissertation, Faculdade de Medicina Veterinária e Zootecnia, Universidade de São Paulo, São Paulo. 
Mainali C, McFall ME, King RK (2011). Validation of a real-time polymerase chain reaction assay for the detection of Salmonella in crops of broiler chickens. Poult. Sci. 90(3): 660-664.

Malkawi HI, Gharaibeh R (2004). Rapid and simultaneous identification of two Salmonella enteric serotypes, Enteritidis and Typhimurium from chicken and meat products by multiplex PCR. Biotechnol. 3(1): 44-48.

Malorny B, Hoorfar J, Bunge C, Helmuth R (2003). Multicenter Validation of the Analytic Accuracy of Salmonella PCR: toward an international standard. Appl. Environ. Microbiol. 69(1): 290-296.

Moganedi KLM, Goyvaerts EMA, Venter SN, Sibara MM (2007). Optimisation of the PCR-invA primers for the detection of Salmonella in drinking and surface waters following a pre-cultivation step. Water. SA 33(2): 195-202.

Murugkar HV, Rahman H, Dutta PK (2003). Distribution of virulence genes in Salmonella serovars isolated from man and animals. Indian. J. Med. Res. 117: 66-70.

Nucera DM, Maddox CW, Hoien-Dalen P, Weigel RM (2006). Comparison of API 20E and invA PCR for Identification of Salmonella enterica Isolates from Swine Production Units. J. Clin. Microbiol. 44(9): 3388-3390.

Rahn K, Degrandis DS, Clarke RC, Mcewen SA, Galan JE, Ginocchoio C, Curtiss RIII, Gyles CL (1992). Amplification of an invA gene sequence of Salmonella typhimurium by polymerase chain reaction as a specific method of detection of Salmonella. Mol. Cell. Probes 6(4): 271-279.

Rampersad J, Johnson J, Brown G, SamLal M, Ammons D (2008). Comparison of polymerase chain reaction and bacterial culture for Salmonella detection in the Muscovy duck in Trinidad and Tobago. Rev. Panam. Salud. Pública. 23(4): 264-267.

Salehi TZ, Mahzounieh M, Saeedzadeh A (2005). Detection of InvA Gene in Isolated Salmonella from Broilers by PCR Method. Int. J. Poultry. Sci. 4(5): 557-559.

Santos DMS, Berchieri Junior A, Fernandes SA, Tavechio AT, Amaral LA (2000) Salmonella em carcaças de frango congeladas. Pesq Vet Bras 20(1): 39-42

Santos LR, Nascimento VP, Oliveira SD, Flôres ML, Pontes AP, Pilotto F, Neves N, Salle CTP, Lopes RFF (2001). Identificação de Salmonella através da reação em cadeia pela polimerase (PCR). UFRGS. 29(2): 87-92.

Silva DSP, Canato T, Magnani M, Alves J, Hirooka EY, Oliveira TCRM (2011). Multiplex PCR for the simultaneous detection of Salmonella spp. and Salmonella Enteritidis in food. Int. J. Food. Sci. Technol. 46(7): 1502-1507.
Soumet C, Ermel G, Rose V et al. (1997) Simultaneous detection by PCR of Salmonella Typhimurium and Salmonella Enteritidis from environmental samples of poultry houses. In: Salmonella and Salmonellosis Proceedings ed. Colin, P., Le Goux, J.M. and Clement, G.. Ploufragan, France: ISPAIA. pp. 53-57.

Soumet C, Ermel G, Rose V, Rose N, Drouin P, Salvat G, Colin P (1999). Evaluation of a multiplex-PCR-based assay for simultaneous identification of Salmonella sp., Salmonella Enteritidis and Salmonella Typhimurium from environment swabs of poultry houses. Lett. Appl. Microbiol. 29(1): 113-117.

Stone GG, Oberst RD, Hays MP, Mcvey S, Galland J, Curtss R, Kelly SM, Chemgappa M (1994). Detection of S.typhimurium from rectal swabs of experimentally infected beagles by short cultivation and PCR hybridization. J. Clin. Microbiol. 33(7): 1292-1295.

Tavechio AT, Fernandes S, Neves BC, Dias AMG, Irino K (1996). Changing patterns of Salmonella serovars: increase of Salmonella enteritidis in São Paulo, Brazil. Rev. Inst. Med. Trop. 38(5): 315-322.

Thorns CJ, Bell MM, Sojka MG, Nicholas RA (1996). Development and application of enzymelinked immunosorbent assay for specific detection of Salmonella enteritidis infections in chickens based on antibodies to SEF14 fimbrial antigen. J. Clin. Microbiol. 34(4): 792797.

Upadhyay BP, Utrarachkij F, Thongshoob J, Mahakunkijcharoen Y, Wongchinda N, Suthienkul O, Khusmith S (2010). Detection of Salmonella InvA Gene in Shrimp Enrichment Culture by Polymerase Chain Reaction. Southeast. Asian. J. Trop. Med. Publ. Health 41(2): 426-435.

Uyttendaele MR, Debevere JM, Lips RM, Neyts KD (1998). Prevalence of Salmonella in poultry carcasses and their products in Belgium. Int. J. Food. Microbiol. 40(2): 1-8.

Wilson MA, RimLer RB, Hoffman LJ (1992). Comparison of DNA Fingerprints and Somatic Serotypes of Serogroup $B$ and $E$ Pasteurella multocida Isolates. J. Clin. Microbiol. 30(6): 1518-1524. 